\title{
Senyawa Phenolik Akar Pisang CV. Kepok (Musa acuminata) yang Diinduksi dengan Fungi Mikoriza Arbuskular Indigenus PU10-Glomus sp 1 terhadap Penyakit Darah Bakteri
}

\author{
Suswati ${ }^{1^{*}}$, Trimurti Habazar'), Eti Farda Husin ${ }^{3)}$, Nasril Nasir ${ }^{4)}$, \\ Dedi Prima Putra ${ }^{5}$, dan Peter Taylor6) \\ 1)Program Studi Pascasarjana, IImu-IImu Pertanian Pemusatan IImu Penyakit Tanaman, \\ Universitas Andalas, Padang 25163 \\ 2)Program Studi Hama dan Penyakit Tanaman, Universitas Andalas, Padang 25163 \\ ${ }^{3)}$ Program Studi Ilmu Tanah, Universitas Andalas, Padang 25163 \\ ${ }^{4)}$ Program Studi Biologi, Universitas Andalas, Padang 25163 \\ 5)Program Studi Farmasi, Universitas Andalas, Padang 25163 \\ 6)Universitas Queenlands, Australia
}

Diterima 18-08-2009 Disetujui 22-09-20110

\begin{abstract}
Cooking banana (Musa acuminata) cv. Kepok is the most susceptible to Blood disease bacterium (BDB) infection. From previous study revealed the best isolate indigenous Arbuscular Mycorrhiza Fungi-Pasar Usang 10 (PU10Glomus sp 1) could induce cv.Kepok resistance to BDB in green house and field experiment. The AMF could change the phenolic compound in root plant. This objectives were to measure the root phenolic compound and bioassay to BDB. The 50 grams fresh inoculant PU10-Glomus sp 1 were applicated to banana root plants 60 days old with 6 levels time course: 12; 24; 36; 48; 72; 92 hours and control (without PU10-Glomus sp 1). The root methanolic extraction followed to Echeverri et al., (2002) methode with vacuum concentration of the filtrate and partitioning into ethyl acetate revealed the presence of an antibacterial compound as detected by TLC (Thin Layer Chromatography), assay phenolic contained by Spectrofotometer UV-Vis 1700 . PharmaSpec. Shimadzu and bioassay using BDB. Nine antibacterial compounds rose from root banana seedling colonized by PU10-Glomus sp 1 in 12 hours after applicated (haa) ; $24 ; 36$ and 48 haa. They were with Rf values of $0.16 ; 0.17 ; 0.19 ; 0.26 ; 0.32 ; 0.37$; $0.71 ; 0.80$ and 0.83 on silica plates run in hexane:ethyl acetate $(1: 2 \mathrm{v} / \mathrm{v})$ and control contained only 0.05 and 0.28 . These compounds produced fluorescens which was bright yellow green spots and purple and have antimicbrobial properties to BDB.
\end{abstract}

Keywords: banana cv.Kepok, induce resistance, phenolic, antibacterium, clear zone growth

\section{PENDAHULUAN}

Senyawa phenolik tersebut memainkan peranan penting dalam perlindungan tanaman terhadap patogen (Grandmaison et al., 1993). Kadar phenolik yang disintesis oleh sel tanaman selama proses HR bervariasi tergantung pada berbagai faktor seperti spesies atau varietas tanaman,tipe jaringan, tipe patogen dan agen induser tanaman. Pada berbagai jenis tanaman pisang Musa sp. yang terserang nematoda ditemukan senyawa phenolik yang berkorelasi dengan pembentukan phenylpropanoid seperti lignifikasi pada pisang jari buaya (AA, Pisang jari buaya group) (Fogain \& Gowen, 1996), akumulasi phenolik pada Yangambi km5 (AAA, lbota group) (Fogain \& Gowen, 1996, Valette et al., 1998), phenylphenalenone phytoalexin pada Musa acuminata (Binks et al., 1997; Luis, 1998), dan proanthocyanidins dalam jumlah tinggi pada pisang Kunnan (AB) (Collingborn et al., 2000). Selain patogen senyawa phenolik pada tanaman juga terinduksi oleh berbagai agen hayati lain seperti fungi mikoriza arbuskular (FMA) (Dixon \& Paiva, 1995).

Introduksi Fungi Mikoriza Arbuskular (FMA) dapat mempengaruhi respon fisiologis dan biokimia tanaman yaitu terjadinya peningkatan produksi senyawa asam salisilat (Blilou et al., 1999), ekspresi gen pertahanan (Harrison \& Dixon, 1993), peningkatan ethylene dan metilasi DNA dalam akar (Dugassa et al., 1996), induksi enzim-enzim hidrolitik (Pozo et al., 1999), peningkatan tingkat PR-protein, akumulasi kandungan phenolik, phytoalexin (Harrison \& Dixon, 1993; Morandi, 1996; Larose et al., 2002); kalose (Cordier et al., 1998b), akumulasi asam salisilat (Blilou et al., 2000a, 2000b;

\footnotetext{
Email: sus_wati@yahoo.com

*Telp: +06281363845116
} 
Medina et al., 2003); kitinase (Rabie \& Almadini, 2005), dan spesies oksigen reaktif (ROS) (Salzer et al., 1999).

Pada berbagai tanaman yang dikolonisasi FMA terjadi perubahan senyawa phenolik dan aktivitas antimikrobanya. Terjadi peningkatan oksidasi dan polymerisasi fenol dalam akar tomat bermikoriza (Dehne \& Schonbeck, 1979), kandungan total fenol terlarut dijumpai dalam akar tanaman kacang tanah yang bermikoriza (Krishna \& Bagyaraj, 1984), deposit phenolik dan enzim hidrolitik pada tanaman wortel terhadap Fusarium oxysporum f.sp. chrysanthemi (Benhamou et al., 1994). Introduksi G. fasciculatum dan penambahan pupuk $P$ pada tanaman kedelai yang diaplikasi pada saat tanam dapat meningkatkan ketahanan terhadap bakteri pustul (Xanthomonas campestris pv. glycines). Dalam ekstrak akar, batang dan daun kedelai tersebut ditemukan senyawa antibakteri dengan nilai Rf 0,4 dan 0,54 (Harmet et al., 1999).

Selain kandungan phenolik juga ditemukan senyawa antimikroba yang tergolong fitoaleksin. Fitoaleksin adalah senyawa toksik yang dilepaskan oleh tanaman di tempat terjadinya infeksi. Fitoaleksin termasuk kedalam beberapa jenis senyawa antara lain : terpenoid, glycocortesoid dan alkaloid yang merupakan kelompok senyawa yang umumnya bersifat lipofilik dan spesifik dalam aktivitas antimikrobanya (Morrissey et al., 1999). Senyawa tersebut memiliki kemampuan merusak dinding sel, memperlambat proses maturasi, merusak metabolisme atau mencegah reproduksi patogen. Inokulasi berbagai jenis FMA pada tanaman kedelai ditemukan peningkatan konsentrasi fitoaleksin: glyocelin, coemestrol dan diadzein yang bersifat antimikroba ( Morandi et al., 1984). Isoflavonoid seperti glyceolin yang bersifat nematostatik dan caumestrol yang bersifat fungitoksis bersama dengan coumestan isosojagol ditemukan dalam jumlah yang lebih tinggi dalam akar tanaman kedelai yang bermikoriza dibanding akar tanpa mikoriza (Morandi \& Le Querre, 1991). Tingkat fitoaleksin medicarpin, coumestrol, daidzein, medicarpin-malonyl glucoside, formononetin, meningkat dalam akar Medicago truncatula pada 7-40 hari setelah introduksi Glomus sp dimana jumlah senyawa tersebut meningkat tajam selama tahap awal kolonisasi kemudian jumlahnya menurun tajam setelah asosiasinya mapan (Harison \& Dixon, 1993).
Kajian kandungan phenolik akar tanaman pisang cv. Kepok yang terkolonisasi FMA-PU10 indigenous dan uji bioaktivitasnya terhadap BDB sampai kini belum ada. Tujuan penelitian adalah untuk mengukur kandungan senyawa phenolik akar pisang cv.Kepok dan uji penghambatan pertumbuhan (bioaktivitas) terhadap BDB.

\section{BAHAN DAN METODE}

Rancangan Penelitian. Pengujian ini menggunakan Rancangan Acak Lengkap (RAL) dengan 3 ulangan. Perlakuan tersebut adalah jam setelah introduksi (jsi) FMA-PU10 (A) dengan 6 taraf yaitu: $A 0=$ kontrol; $A 1=4$ jsi; $A 2=12$ jsi; $A 3=24$ jsi; $A 4=36$ jsi; $A 5=48$ jsi; $A 6=72$ jsi; $A 7=96$ jsi sebagai pembanding digunakan akar tanaman pisang umur 8 bulan setelah tanam (bst) di lahan endemik BDB.

PU10-Glomus sp 1 merupakan FMA indigenus yang dapat meningkatkan ketahanan tanaman pisang terhadap BDB (hasil penelitian awal). PU10-Glomus sp 1diperbanyak pada tanaman jagung selama 2 bulan, kemudian dipanen. Aplikasi PU10-Glomus sp 1dilakukan pada bibit pisang umur 2 bulan setelah aklimatisasi dengan cara membuat koakan disekitar perakaran tanaman, kemudian sebanyak 50 gram inokulan segar PU10-Glomus sp 1 diletakkan disekitar akar, diupayakan agar terjadi kontak antara inokulant dengan akar, selanjutnya ditutup dengan media tanam. Tanaman dibongkar sesuai dengan waktu perlakuan, bagian akar diambil untuk dianalisis fitoaleksinnya.

Ekstraksi dan Fraksinasi. Ekstraksi dan fraksinasi akar tanaman pisang menggunakan metode Echeverri et al., (2002). Sebanyak 100 gram akar tanaman pisang cv.Kepok yang telah diberi perlakuan dicuci dan dikeringkan dalam oven suhu $40^{\circ} \mathrm{C}$, hingga kadar air 10\% kemudian di potong-potong ukuran $1 \mathrm{~cm} \times 1 \mathrm{~cm}$, digrinder dan diayak (lolos saringan 180 $\mu \mathrm{m})$. Sebanyak $10 \mathrm{gr}$ tepung akar pisang dimasukkkan kedalam botol kemudian direndam dalam $100 \mathrm{ml}$ etil asetat, selama 3 hari. Perendaman dilakukan sebanyak $2 \times 100 \mathrm{ml}$ etil asetat. Hasil perendaman disaring, kemudian diuapkan dengan rotary evaporator hingga $25 \%$ volume sisa. Ekstrak EtOAc diuji kandungan phenolik totalnya dan kemampuan menghambat pertumbuhan bakteri BDB (uji bioaktivitas).

Analisis kualitatif kandungan phenolik total. Kandungan total phenolik sampel akar diuji dengan 
menggunakan metode Folin-Ciocalteu. Sebanyak $0,001 \mathrm{gr}$ fraksi etil asetat akar ditambahkan dengan $1 \mathrm{ml}$ methanol. Perlakuan tersebut dilakukan secara terpisah untuk masing-masing perlakuan. Maserat diambil dengan pipet mikro sebanyak $250 \mu \mathrm{l}$, kemudian ditambahkan dengan 2,75 ml Reagen Folin Calceur (pengenceran 1:20) dan $2 \mathrm{mI} \mathrm{Na}_{2} \mathrm{CO}_{3}$. Larutan tersebut diinkubasi pada suhu $40^{\circ} \mathrm{C}$ selama 10 menit. Kandungan phenolik total diukur menggunakan Spektrofotometer UV-Vis1700.PharmaSpec. (Shimadzu ${ }^{\circledR}$ ) pada $\lambda 765 \mathrm{~nm}$, masing-masing perlakuan dilakukan pengukuran sebanyak 3 kali. Standar kurva kalibrasi asam gallat dinyatakan equivalent per gram berat segar akar.

Analisis Kromatografi Lapis Tipis. Pemeriksaan dengan KLT dilakukan dengan fasa diam plat silika gel GF254 dengan pengembang hexan - etil asetat (2:1). Sebanyak 0,001 gr fraksi etil asetat akar ditambahkan dengan $1 \mathrm{ml}$ methanol, kemudian $10 \mu \mathrm{l}$ fraksi etil asetat tersebut ditotolkan pada plat KLT, dibiarkan kering dan dikembangkan dengan hexan - etil asetat (2:1). Sebagai standar digunakan asam salisilat dan asam benzoat. Pita yang terbentuk pada plat KLT dilihat dibawah lampu UV Camag pada panjang gelombang $366 \mathrm{~nm}$.Masingmasing pita yang tampak tersebut dihitung nilai Rf-nya.

Uji bioaktivitas. Uji bioaktivitas antimikroba dilakukan dengan metode kertas cakram (Habazar, 1989). Fraksi etil asetat sebanyak $0,001 \mathrm{gr}$ ditambah dengan $1 \mathrm{ml}$ DMSO, diaduk hingga maserat terlarut sempurna. Setiap kertas cakram dibasahi dengan $10 \mu$ fraksi etil asetat kemudian diletakkan dalam biakan bakteri penyakit darah, masing-masing perlakuan diulang 3 kali. Biakan bakteri diinkubasikan pada suhu kamar selama 48 jam. Terbentuknya daerah hambatan pertumbuhan bakteri menunjukkan adanya senyawa antimikroba pada akar. Untuk mengetahui adanya pita-pita yang aktif dan tidak aktif sebagai senyawa antibakteri maka plat KLT disemprot dengan suspensi BDB pada medium TZC agar $1 \%$ (populasi $10^{6}$ upk $\mathrm{ml}^{-1}$ ), kemudian dimasukkan ke dalam cawan petri diameter $15 \mathrm{~cm}$ untuk diinkubasikan selama 48 jam pada suhu kamar $(\mathrm{RH}>96 \%)$. Daerah hambatan pertumbuhan BDB ditandai dengan jernihnya (clear zone) pada plat KLT yang membuktiksan adanya senyawa antibakteri.

Pengamatan. Kandungan phenolik total fraksi etil asetat akar tanaman pisang diukur dengan penentuan nilai absorbansi masing-masing ekstrak dengan Spektrofotometer UV-Vis 1700. PharmaSpec. $\left(\right.$ Shimadzu ${ }^{\circledast}$ ) pada panjang gelombang $765 \mathrm{~nm}$. Nilai absorbansi yang diperoleh dikonversi ke persamaan regresi senyawa standar asam galat yaitu $Y=0,0156 X-0,0195 ; R^{2}=0,9992$, di mana $Y=$ Kandungan phenolik, $X=$ Nilai absorbansi.

Kemampuan fraksi etil asetat dalam menghambat tumbuh BDB dihitung dengan menggunakan rumus $L=2 \pi r$, dimana $L=$ luas daerah zona hambat tumbuh $\mathrm{BDB}, r=$ jari-jari daerah hambat tumbuh BDB.

Terbentuknya pita-pita fraksi etil asetat akar tanaman yang diaplikasi FMA pada plat KLT di amati dengan mengukur nilai Rf masing-masing pita dengan rumus:

$$
R f=\frac{\text { Jarak relatif yang ditempuh kom ponen }}{\text { Jarak yang ditem puh pela rut pengem bang }}
$$

\section{HASIL DAN PEMBAHASAN}

Kandungan Phenolik Total. Kandungan phenolik total fraksi etil asetat akar tanaman pisang diukur dengan penentuan nilai absorbansi masing-masing ekstrak dengan Spektrofotometer UV-Vis 1700. PharmaSpec.(Shimadzu ${ }^{\circledast}$ ) pada panjang gelombang $765 \mathrm{~nm}$ yang diulang 3 kali. Aplikasi FMA menyebabkan teraktivasinya mekanisme pertahanan tanaman melalui perobahan kandungan phenolik akar tanaman. Senyawa tersebut terdapat dalam jumlah rendah pada awal kolonisasi kemudian meningkat seiring dengan bertambahnya waktu kolonisasi FMA (Tabel 1). Pada awal kolonisasi PU10-Glomus sp 1 menyebabkan penurunan kandungan phenolik akar cv.Kepok sebesar

Tabel 1. Kandungan phenolik total akar tanaman pisang cv Kepok setelah aplikasi FMA-PU10 pada waktu yang berbeda diuji dengan Spektrofotometer UV-Vis 1700

\begin{tabular}{ccccc}
\hline Bahan uji & Waktu perlakuan (jam) & $\begin{array}{c}\text { Konsentrasi } \\
(\mu \mathrm{g} / \mathrm{ml})\end{array}$ & $\begin{array}{c}\text { kandungan phenolik total } \\
(\text { rata-rata } \pm \text { stdev }) \mu \mathrm{g} / \mathrm{ml}\end{array}$ & $\begin{array}{c}\text { Perubahan kandungan } \\
\text { phenolik }(\%)\end{array}$ \\
\hline Kontrol & 0 & 1 & $10,481 \pm 1,994$ & 0,000 \\
FMA-PU10 & 12 & 1 & $4,113 \pm 2,590$ & $-60,760$ \\
& 24 & 1 & $5,865 \pm 2,629$ & $-44,040$ \\
& 36 & 1 & $7,596 \pm 2,774$ & $-27,530$ \\
& 48 & 1 & $8,130 \pm 2,290$ & $-22,430$ \\
LFMA PU-10 & 72 & 1 & $9,903 \pm 6,164$ & $-5,510$ \\
LKontrol & 8 bulan setelah tanam di lahan endemik BDB & 1 & $10,502 \pm 3,634$ & 0,200 \\
\hline
\end{tabular}


60,76\% (12 jsi) dan 5,51\% (72 jsi), kemudian mengalami sedikit peningkatan $(0,20 \%)$ pada 96 jsi. Peningkatan yang cukup tajam sebesar 153,82\% ditemukan dalam ekstrak akar tanaman yang telah 8 bst di lapangan.

Analisis Kromatografi Lapis Tipis. Hasil pengujian fraksi etil asetat yang dielusi dengan pelarut heksan: etil asetat $(1: 2 \mathrm{v} / \mathrm{v})$ pada plat KLT diperoleh beberapa pita yang berfluorescens kuning hijau cerah dan ungu dibawah sinar UV Camag pada $\lambda 366 \mathrm{~nm}$ yang memiliki nilai Rf berbeda (Tabel 2 ). Terjadi penambahan beberapa pita baru dengan nilai Rf yang berbeda pada 12 jsi hingga 48 jsi, kemudian jumlah pita berkurang dari 72 jsi -96 jsi. Hal ini diduga bahwa aplikasi PU10-Glomus sp 1 menyebabkan terbentuknya jenis senyawa phenolik baru yang memiliki aktivitas berbeda dengan senyawa phenolik akar kontrol.

Analisis Bioaktivitas. Uji bioaktivitas fraksi etil asetat dengan metode kertas cakram diperoleh bahwa senyawa phenolik akar tanaman bermikoriza memiliki sifat anti bakteri yang lebih tinggi dibanding kontrol (Tabel 3). Masing-masing perlakuan memberikan hasil yang berbeda dalam menghambat pertumbuhan bakteri tersebut. Aktivitas antibakteri senyawa phenolik akar tanaman pisang bermikoriza meningkat 53,40\%-100,00\%. Aplikasi PU10-Glomus sp 1 setelah 24 jsi akan meningkatkan aktivitas antibakteri senyawa phenolik hingga 100\%. Sebagai pembanding juga dilakukan analisis bioaktivitas senyawa phenolik akar tanaman pisang sehat dan tanaman pisang yang terserang secara alami di lahan endemik BDB.
Ditemukan bahwa aktivitas senyawa phenolik tanaman tersebut memiliki aktivitas yang tergolong tinggi yaitu $126,60 \%$ sedang pada akar sehat aktivitasnya lebih rendah (46,60\%). Hasil uji dengan metode kertas cakram selaras dengan hasil uji antibakteri pada plat KLT. Ditemukan tidak adanya pertumbuhan pada pita-pita aktif yang ditandai dengan zona terang (clear zone) sedang pada pita-pita tidak aktif ditemukan adanya pertumbuhan bakteri yang ditandai dengan warna agak gelap.

Tanaman pisang cv.Kepok merupakan jenis pisang yang sangat respon terhadap introduksi FMA. Pada pengujian awal diperoleh bahwa isolat PU10-Glomus sp 1 dapat meningkatkan ketahanan cv.Kepok terhadap BDB dalam pengujian rumah kaca dan lapangan (Suswati et al., 2008). Mekanisme peningkatan ketahanan cv.Kepok terhadap BDB setelah diaplikasi dengan PU10-Glomus sp 1 diketahui melalui perubahan jumlah senyawa phenolik akar dan aktivitas antibakteri. Pada awal kolonisasi (12-72 jsi) kandungan phenolik menurun kemudian mengalami peningkatan secara lambat dan rendah setelah 96 jsi. Respon tanaman akibat introduksi FMA ini berjalan pada waktu yang pendek khususnya di awal infeksi dan untuk selanjutnya terjadi interaksi yang harmonis antara inang dan fungi sehingga respon ketahanan berkurang/dapat ditekan. Hasil yang diperoleh berbeda dengan penelitian yang dilakukan oleh Krishna dan Bagyaraj (1984), dimana aplikasi mikoriza menyebabkan terjadi peningkatan kandungan total phenol terlarut akar

Tabel 2. Nilai Rf fraksi ethyl acetat akar tanaman pisang yang diinduksi dengan FMA-PU10 pada plat Kromatografi Lapis Tipis

\begin{tabular}{|c|c|c|}
\hline Bahan uji & Waktu perlakuan (jam) & Nilai Rf \\
\hline Kontrol & 0 & 0,$05 ; 0,28^{* *}$ \\
\hline \multirow{6}{*}{ FMA } & 12 & $0,06^{\star *} ; 0.19^{* \star} ; 0,32^{\star *} ; 0,80^{* *}$ \\
\hline & 24 & $0,05^{\star} ; 0,16^{\star *} ; 0,37^{\star *} ; 0,71^{\star *}$ \\
\hline & 36 & $0,03^{\star *} ; 0,17^{\star *} ; 0,71^{* *}$ \\
\hline & 48 & $0,05^{\star} ; 0,26^{\star *} ; 0,83^{* *}$ \\
\hline & 72 & $0,06^{\star *}$ \\
\hline & 96 & $0,04^{\star *}$ \\
\hline Asam salisilat & & $0,22^{*}$ \\
\hline Asam benzoat & & $0,33^{*}$ \\
\hline
\end{tabular}

Keterangan : "= pita tidak aktif; ${ }^{*}=$ pita aktif

Tabel 3. Zona hambat ekstrak fraksi etil asetat akar tanaman pisang setelah aplikasi FMA-PU10 pada waktu yang berbeda

\begin{tabular}{|c|c|c|c|c|}
\hline Bahan uji & Waktu perlakuan (jam) & $\begin{array}{l}\text { Konsentrasi } \\
(\mu \mathrm{g} / \mathrm{ml}\end{array}$ & $\begin{array}{c}\text { Zona hambat (rata-rata } \pm \text { stdev) } \\
(\mathrm{mm})\end{array}$ & Peningkatan (\%) \\
\hline Kontrol & 0 & 1 & $5,00 \pm 0,00$ & 0,00 \\
\hline \multirow[t]{6}{*}{ FMA-PU10 } & 12 & 1 & $7,67 \pm 0,57$ & 53,40 \\
\hline & 24 & 1 & $10,00 \pm 3,46$ & 100,00 \\
\hline & 36 & 1 & $9,00 \pm 1,00$ & 80,00 \\
\hline & 48 & 1 & $8,00 \pm 0,00$ & 62,60 \\
\hline & 72 & 1 & $9,00 \pm 1,73$ & 98,06 \\
\hline & 96 & 1 & $8,67 \pm 1,15$ & 73,40 \\
\hline LFMA PU-10 & 8 bulan setelah tanam di lahan endemik BDB & 1 & $11,33 \pm 2,52$ & 126,60 \\
\hline LKontrol & 8 bulan setelah tanam di lahan endemik BDB & 1 & $7,33 \pm 0,58$ & 46,60 \\
\hline
\end{tabular}


kacang tanah, deposit phenolik dan enzim hidrolitik pada tanaman wortel bermikoriza terhadap Fusarium oxysporum f.sp. chrysanthemi (Benhamou et al., 1994). Sedang pada perakaran tanaman kedelai dan spesies Medicago yang bermikoriza dilaporkan bahwa akumulasi fitoaleksin atau prekursor fitoaleksin terjadi secara lambat, rendah dan sementara (Morandi et al., 1984; Harrison \& Dixon, 1993; Volpin et al., 1995), dan ekspresi gen yang mengkode biosintesa enzim PAL (pada tahap awal/early stage) (Harrison \& Dixon, 1993; Volpin et al., 1994,1995). Sementara pada tanaman buncis, parsley atau akar tanaman kentang tidak terjadi perubahan aktivitas PAL dan akumulasi fitoaleksin (Lambais \& Mehdy, 1993). Penurunan kandungan phenolik akar tanaman pisang yang diaplikasi PU10-Glomus sp 1 berkorelasi positif dengan penurunan aktivitas enzim PAL dalam akar tersebut pada awal kolonisasi (12 jsi-72 jsi) sedang pada 96 jsi terjadi peningkatan walaupun dalam jumlah rendah (Suswati et al., 2009). Setelah tanaman dipindah ke lahan endemik BDB, terjadi peningkatan kandungan phenolik yang cukup besar pada tanaman pisang bermikoriza $(153,820 \%)$ sedang kontrol hanya $6,670 \%$. Menurut García-Garrido dan Ocampo (2002), tanaman akan terstimulasi lebih kuat dalam mengaktivasi mekanisme pertahanan pada saat patogen menyerang tanaman. Menurut berbagai hasil penelitian sebelumnya diketahui bahwa mekanisme pertahanan tumbuhan diaktifkan lebih cepat dan lebih besar di dalam tanaman yang bermikoriza pada saat adanya serangan patogen dibanding tanaman tanpa mikoriza.

Kandungan phenolik, fitoaleksin yang disintesis oleh sel tanaman selama proses patogenisitas bervariasi tergantung pada berbagai varietas tanaman, tipe jaringan dan tipe patogen. Produksi senyawa tersebut dalam skala besar hanya terdapat pada kombinasi ras bakteri dan varietas yang inkompatibel tetapi juga ditemukan dalam kadar rendah dalam kombinasi kompatibel (Habazar \& Rivai, 2000). Tingkat fitoaleksin medicarpin, coumestrol, daidzein, medicarpin-malonyl glucoside, formononetin, meningkat dalam akar Medicago truncatula pada 7- 40 hari setelah introduksi Glomus sp (Harison \& Dixon, 1993).

Hasil pengujian senyawa aktif antibakteri pada plat KLT diperoleh bahwa aplikasi PU10-Glomus sp 1 akan menyebabkan terinduksinya ketahanan tanaman yaitu dengan terbentuknya beberapa senyawa aktif yang terdeteksi dengan munculnya pita-pita baru yang memiliki nilai $\mathrm{Rf}$ yang berbeda dengan kontrol. Jumlah pita aktif tersebut kemungkinan dipengaruhi oleh lamanya masa kolonisasi mikoriza. Pada awal kolonisasi terdapat 4 pita aktif dengan nilai $\mathrm{Rf}$ $0,06,0,19,0,32,0,80$, pada 24 jsi terdapat 3 pita aktif dengan nilai $R f 0,16,0,37,071$ pada 36 jsi juga terdapat 3 pita aktif pada Rf 0,03,0,17 dan 0,71. Pada 48 jsi terjadi pengurangan pita aktif menjadi 2 buah yaitu pada Rf 0,26 dan 0,83 , sedang pada akhir kolonisasi 72 jsi dan 96 jsi hanya terdapat masing-masing 1 pita aktif dengan nilai $R f$ berturut-turut 0,06 dan 0,04, sedang kontrol memiliki 2 pita dengan nilai Rf 0.05 dan 0.28 . Senyawa standar asam salisilat dan benzoat memiliki nilai Rf 0,22 dan 0,33. Hasil penelitian Plumbley and Sweetmore, (2001), dalam fraksi etil asetat daun yam (Dioscorea alata) yang peka terhadap penyakit antraknosa (Colletotrichum gloeosporioides) ditemukan hanya satu pita dengan nilai $R f 0,32$ sedang pada tanaman yang resisten ditemukan adanya tiga pita baru yang muncul yang tergolong senyawa phenolik dengan nilai Rf: 0,15, 0,21 dan 0,39 dan memiliki aktivitas antifungi. Inokulasi $G$ fasciculatum dan penambahan pupuk $P$ pada tanaman kedelai yang diaplikasi pada saat tanam dapat meningkatkan ketahanan terhadap bakteri pustul (Xanthomonas campestris pv. glycines), dalam ekstrak akar, batang dan daun ditemukan senyawa antibakteri dengan nilai $\mathrm{Rf} 0,4$ dan 0,54 (Harmet et al., 1999).

Aktivitas antibakteri senyawa phenolik dengan jelas dapat diukur dalam pengujian bioassay dengan metode kertas cakram. Aktivitas antibakteri meningkat dari 53,40\% (12 jsi) hingga 100\% pada 24 jsi. Pada pengujian aktivitas antibakteri pada plat KLT diketahui bahwa sebagian besar pita yang muncul akibat aplikasi FMA memiliki aktivitas antibakteri. Hal ini sesuai dengan penelitian Morandi et al., (1996), inokulasi berbagai jenis FMA pada tanaman kedelai dapat meningkatkan konsentrasi fitoaleksin: glyocelin, coemestrol dan diadzein yang bersifat antimikroba. Isoflavonoid seperti glyceolin yang bersifat nematostatik dan caumestrol yang bersifat fungitoksis bersama dengan coumestan isosojagol ditemukan dalam jumlah yang lebih tinggi dalam akar tanaman kedelai yang bermikoriza dibanding akar tanpa mikoriza (Morandi \& Le Querre, 1991). Pada tanaman yang terserang oleh mikroorganisme patogen juga ditemukan 
fitoaleksin dan peningkatan enzim pertahanan. Hasil penelitian Echeverri et al., (2002), ditemukan beberapa jenis fitoaleksin dari kelompok isoflavonoid di dalam daun dan akar tanaman pisang akibat serangan Mycosphaerella fijiensis dan Fusarium oxysporum yaitu: 9-phenylphenalenones; 4- phenylphenalenones; irenolone; 4'-methoxyirelone; musanolones dan dari bagian buah yang terserang Colletotrichum musae telah diidentifikasi 17 derivat phenylphenalenone.

\section{KESIMPULAN}

Aplikasi PU10-Glomus sp 1 indigenous akan mengaktivasi ketahanan tanaman melalui peningkatan kandungan senyawa phenolik. Kandungan senyawa tersebut pada awal kolonisasi mengalami penurunan kemudian jumlahnya meningkat seiring dengan lamanya waktu kolonisasi mikoriza. Senyawa phenolik tersebut dapat menghambat pertumbuhan BDB (antibakteri).

\section{UCAPAN TERIMAKASIH}

Ucapan terima kasih di sampaikan kepada Direktur Dikti, DP2M yang telah memberikan Dana Penelitian kegiatan ini yang merupakan program kerjasama antara Universitas Medan Area dengan DIKTI, sesuai dengan Surat Perjanjian Pelaksanaan Pekerjaan Penelitian Nomor : 078/SP2H/PP/DP2M/III/2008.

\section{DAFTAR PUSTAKA}

Benhamou, N., Fortin, J.A., Hamel, C., St-Arnaud, M. \& Shatilla, A. 1994. Resistance responses of mycorrhizal Ri T-DNA-transformed carrot roots to infection by Fusarium oxysporum f.sp. chrysanthemi. Phytopathology 84: 958-968.

Binks, R.H. 1996. Aspects of biochemical resistance in Musa spp. Nematropica 26: 243.

Binks, R.H., Greenham, J.R., Luis, J.G. \& Gowen, S.R. 1997. A phytoalexin from roots of Musa acuminata var. "Pisang sipulu". Phytochemistry 45: 47-49.

Blilou, I., Ocampo, J.A. \& Gracia-Garrido, J.M. 1999 Resistance of pea roots to endomycorrhizal fungus or Rhizobium correlates with enhanced levels of endogenous salicylic acid. J. Exp. Bot 50: 1663-1668.

Blilou, I., Bueno, P., Ocampo, J.A. \& Garcia-Garrido, J.M. 2000a. Induction of catalase and ascorbate peroxidase activities in tobacco roots inoculated with the arbuscular mycorrhizal Glomus mosseae. Mycological Research 104: 722-725.

Blilou I, Ocampo, J.A. \& García-Garrido, J.M. 2000b. Induction of Ltp (Lipid transfer protein) and $\mathrm{Pal}$ (Phenylalanine ammonia-lyase) gene expression in rice roots colonized by the arbuscular mycorrhizal fungus Glomus mosseae. J Exp Bot 51:1969-1977

Brundrett, M., Abbot, L.K., Jasper, D.A. \& Aswath, N. 1994. Mycorrhizal association in Disturbed and Natural Habitats in Tropical Australia Mycorrhizas for plantation Forestry in Asia. Proceeding of International Symposium and workshop, Kaping, Guandong Province, P.R. China 7-11 November 1994. Editors M.Brundrett, B.dell. Maljczuk and Gong Mingqin. P.3440.
Campbell, R. 1989. Effect of Glomus intraradices on infection by Fusarium oxysporum f.sp.radicis lycopersici in tomatoes 12 week period. Canadian Journal Botany 64: 552-556.

Collingborn, F.M.B., Gowen, S.R. \& Mueller-Harvey, I. 2000. Investigations into the biochemical basis for nematode resistance in roots of three Musa cultivars in response to Radopholus similis infection. Journal of Agricultural and Food Chemistry 48: 5297-5301.

Cordier, C., Pozo, M.J., Gianinazzi, S. \& Gianinazzi-Pearson, V. 1998b. Cell defence responses associated with localised and systemic resistance to Phytophthora parasitica induced in tomato by an arbuscular mycorrhizal fungus. Mol. Plant Microbe Interc 11:1017-1028.

Dehne, H.W. \& Schönbeck, F. 1979. Untersuchungen zum einfluss der endotrophen Mycorrhiza auf Pflanzenkrankheiten: II. Phenolstoffwechsel und lignifizierung. Phytopath.Z. 95: 210-216.

Dehne, H.W. 1992. Interaction between vesicular arbuscular mycorrhizae fungi and plant pathogens. Phytopathology.

Dixon, R.A., Harrison, M.J., Paiva, N.L. 1995. The isoflavonoid phytoalexin pathway: From enzymes to genes to transcription factors. Physiologia Plantarum 93: 385-392.

Dugassa, G.D., von Alten, H. \& Schonbeck, F. 1996. Effect of arbuscular mycorrhiza (AM) on health of Linum usitatissimum L. infected by fungal pathogens. Plant Soil, 185: 173-18.

Echeverri, F., Quinones, W., Torres, F. \& Scheinede, B. 2002. Correlation Between phenylphenalenones phytoalexins and phytopathological properties In Musa and role of a dehydrophenylphenalenonetriol. Molecules 7: 331-340.

Fogain, R. \& Gowen, S.R. 1996. Investigations on possible mechanism of resistance to nematodes in Musa. Euphytica 92: 375-381.

Garcia-Garrido, J.M. \& Ocampo, J.A. 2002. Regulation of the plant defence response in arbuscular mycorrhizal symbiosis. Journal of experimental Botany 53: 1377-1386.

Grandmaison, J., Olah, G.M., van Calsteren, M.R. \& Furlan, V. 1993. Characterization and localizatioin of plant phenolics likely involved in the pathogen resistance expressed by endomycorrhizal roots. Mycorrhiza 3:155-164.

Habazar, T. \& Rivai, F. 2000. Dasar-Dasar Bakteri Patogenik Tumbuhan. Fakultas Pertanian. Universitas Andalas. Padang.

Harison, M.J. \& Dixon, R.A. 1993. Isoflavonoid accumulation and expression of defence gene transcripts during the establishment of vesicular-arbuscular mycorrhizal associations in roots of Medicago trunculata. Mole. Plant Microbe Interac 6: 643-654.

Harmet. 1999. Peranan G. fasciculatum dan pupuk fosfor dalam peningkatan ketahanan tanaman kedelai terhadap penyakit pustul bakteri $(X c g)$. Thesis program pascasarjana Universitas Andalas Padang. 73 hal.

Kobayashi, N. \& Branch, K. 1991. Biological control of soil borne disease with vesicular arbuscular mycorrhiza fungi and charcoal compost. In: Proceeding of the international seminar biological control of plant disease and Virus vektor. Sept 1721, Tsukuba. Japan 153-160.

Krishna, K.R. \& Bagyaraj, D.J. 1984. Phenols in mycorrhizal roots of Arachis hypogaea. Experientia 40: 85-86.

Larose, G,, Chenevert., Moutoglis, P., Gagne, S., Piché \& Vierheilig, H. (2002). Flavonoid levels in roots of Medicago sativa are modulated by the developmental stage of the symbiosis and the root colonizing arbuscular mycorrhizal fungus. J Plant Physiol 159: 1329-1339.

Luis, J.G. 1998. Phenylphenalenone-type phytoalexins and phytoanticipins from susceptible and resistance cultivars of Musa species. Its potential for engineering resistance to fungi and nematodes into banana. Acta Horticulturae 490: 425430.

Medina, H.M.J., Gagnon, H., Piché, Y., Ocampo, J.A., García Garrido, J.M. \& Vierheilig, H. (2003) Root colonization by arbuscular mycorrhizal fungi is affected by the salicylic acid content of the plant. Plant Sci 164: 993-998.

Morandi, D., Baily, J.A. \& Gianinazzi-Pearson, V. 1984. Isoflavonoid accumulation in soybean roots infected with 
vesicular-arbuscular mycorrhizal fungi. Physiol. Plant Patho 24: 357-364.

Morandi, D. \& Le Querre, J.L. 1991. Influence of nitrogen on accumulation of isosojagol ( a newly detected coumestan in soybean) and associated isoflavonoids in roots and nodules of mycorrhizal and non-mycorrhizal soybean. New Phyto 117: 75-79.

Morandi, D. 1996. Occurrence of phytoalexins and phenolics compounds in endomycorrhizal interaction and their potential role in biological control. Plant and Soil 185: 241-251.

Morrissey, John. P., Osburn., Anne, E. \& Fungal Resistance to Plant Antibiotics as a Mechanism of Pathogenesis. 1999. Microbilogy and Molecular Biology Reviews. 708-724.

Pozo, M.J., Azcón-Aguilar, C., Dumas-Gaudot, E. \& Barea, J.M. 1999. B-1,3-glucanase activities in tomato roots inoculated with arbuscular mycorrhizal fungi and/or Phytophthora parasitica and their possible involvement in bioprotection. Plant Sci 141:149-157.

Plumbley, R.A \& Sweetmore, A. 2001. Phenolic compounds and resistance of Yam (Dioscorea alata) to Anthracnose caused by Colletotrichum gloeosporioides. International Symposium on Natural Phenols in Plant Resistance. Acta Horticulturae. 381.
Salzer, P., Corbière, H. \& Boller, T. 1999. Hydrogen peroxide accumulation in Medicago truncatula roots colonized by the arbuscular mycorrhiza-forming fungus Glomus mosseae. Planta 208: 319-325.

Sieverding, E. 1991. Vesicular- arbuscular mycorrhiza management in tropical agrosystems. GTZ GmbH. Germany. pp. 371.

Smith, S.E. \& Read, D.J. 1997. Mycorrhizae syimbios. Academic press. Harcourt brace \& Company, Publisher, UK. pp. 605.

Suswati, Habazar, T., Husin, E.F., Nasir, N., Putra, D.P. \& Taylor, P.A. 2008. Seminar Nasional dan Workshop Mikoriza Indonesia, Fakultas Ekonomi Universitas Andalas, Padang 12- 15 November 2008.

Suswati, Habazar, T., Husin E.F., Nasir, N., Putra, D.P. \& Taylor, P.A. 2009. Phenylalanine Ammonia-lyase Activity In Plantain cv.Kepok Induced by PU10-AMF. The $2^{\text {nd }}$ International Seminar And Workshop On Advance Molecular Biology.Pangeran Beach Hotel, Padang. August $17^{\text {th }}-20^{\text {th }} 2009$.

Valette, C., Andary, C., Geiger, J.P., Sarah, J.L. \& Nicole, M. 1998. Histochemical and cytochemical investigations of phenols in roots of banana infected by the burrowing nematode Radopholus similis. Phytopathology, 88: 11411148. 